\title{
Empresses and Buddhism in Japan in VI-VIII cc
}

\author{
Elena Lepekhova \\ Russian Academy of Sciences, Moscow, Russia
}

\begin{abstract}
The basic problem of given paper is a role of women-empresses in the process of spreading Buddhism in Japan during VI-VIII cc. There are many evidences that during the process of spreading Buddhism in the Far East and South-East Asia, the principles of Buddhist doctrine became a part of the state ideology in many cases due to the patronage of the powerful laywomen. In Japan, thanks to the activity of empresses Suiko (597-628), Jito (645-703) and Kōken (718-770). Buddhism could integrate into the system of traditional religion Shinto, developing further into Shinto-Buddhist syncretism. During the reign of Suiko about a hundred of the Buddhists, temples have been constructed through all the country and a system of religious bureaucracy "Sōgō" was founded. Empress Jitō took part in religious reforms during the second half of VII century and sent Buddhist missionaries to the local aborigines haya to and emishi. Empress Kōken after the death of her father-emperor Shōmu continued his policy to constructing the state ideology on the basis of Buddhism and was the first ruler in the history of early-medieval Japan, who permitted Buddhists to take part in the Shinto ceremonies. Therefore, the study of the role of empresses in spreading of Buddhism in Japan is important for understanding the history of religious and cultural traditions in Japan.
\end{abstract}

Keywords: Buddhism, Japan, Suiko, Jitō, Kōken, "Sōgō”, hayato, emishi, Shōmu, Shinto

\section{Introduction}

The introduction of Buddhism to Japan is dated by 552 in "Nihon Shōki” 日本書紀 “The Annals of Japan”, when the Koreanking Sonmyōn wan 聖明王 (or Seong) of Baekje (Jp. Kudara) 百濟 sent a mission to Japan that included some Buddhist monks, together with an image of Buddha and a number of sutras to introduce Buddhism. As the chronicle reports, the emperor Kimmei 欽明 (509-571), after receiving the Korean embassy and accepting the gifts, asked the advice of his three chief counselors: oomi 大臣 (Great Imperial chieftain, or Great Minister) Soga-no Iname 蘇我稲目, ommuraji (Great Deity chieftain) Mononobe-no Okoshi 物部尾輿 and the other omuraji (Great Deity chieftain) Nakatomi-no Kamako 中臣鎌子 about the acceptance of a new religion.

While both Mononobe and Nakatomi were against the acceptance of Buddhism, oomi Soga-no Iname supported the new religion. Therefore, the emperor granted to him the stone image of Buddha, and Iname placed it in Owarida palace, later transformed into Buddhist temple ("Nihon Shōki", V. II, 1973, pp. 89-90).

In the temple chronicle "Gangōji Garan Engi Narabi ni Ruki Shizaichō" (元興寺伽藍縁起并流記資財帳, "Origins of the Gangōji Monastery and Its Assets"), composed in the second half of the VIII century, is given

Elena Lepekhova, Ph.D., Doctor of Philosophy, Senior Research Officer, Institute of Oriental Studies, Russian Academy of Sciences.

Correspondence concerning this article should be addressed to 107031, Moscow, Rogdestvenka 12, Russia. 
another version about the date 538, which included Empress Suiko 推古 (554-628). It says that the emperor, on the advice of Minister Soga-no Iname, ordered to place a statue of the Buddha in the palace of Suiko in Mukuhara 牟原 (Gangoji garan engi, 1975, p. 85).

\section{Empress Suiko and the Spreading of Buddhism in Japan in VII c.}

Empress Suiko 推古 (554-628) was the first of the Japanese empresses of Asuka-Nara period. Her reign marked the beginning of a tradition when the Empresses Dowagers ascended the throne during VII-VIII centuries. Suiko came to power with the support of the powerful Minister Soga-no Umako 蘇我馬子 (the son of Soga-no Iname) - supporter of the teachings of Buddha, who had previously managed to remove from the power their rivals - aristocratic clans Nakatomi and Mononobe, who opposed to the adoption of Buddhism. According to the chronicles "Nihon Shōki", and "Gangoji Garan Engi", the Empress was also a supporter of the new religion. The first thing she ordered to do, upon ascending the throne, was the construction of Buddhist temples through the country: "The Empress ordered to the Crown Prince [Shōtoku] to further the flourishing of Three Treasures (kōryū sanbō 興隆三寶). At this time, all the ōmi and muraji, competing with each other, built the houses for the welfare of their lords and parents. These houses were called the [Buddhist] temples (o-tera 寺)” (“Nihon Shōki”, V. II, 1973, p. 131).

In 605 and 606, according to the "Nihon Shōki", the Empress ordered to Crown Prince Shōtoku-taishi 聖 徳太子, ministers and governors of the provinces to make two images of Buddha, made of copper and embroidery 銅紼佛像 (dōjū butsuzō) (probably, it was the mandala with images of Buddhas). In 606, under the guidance of the master Tori, was made the first copper statue of Buddha in Japan. Its height was about 16 shaku and later it was installed in Gangoji Temple 元興寺. In honor of this event, in the fourth month of the same year, in the temple was arranged a great prayer ceremony of the Buddhist monks, called kambutsu-e (灌 仏会). It symbolized the emergence of Shakyamuni Buddha in the world of samsara. Probably, the creation of the first monumental Buddha statue in Japan by the order of Empress Suiko, placing this one in Buddhist temple Gangoji, and arrangement of Buddhist prayer ceremony, in the eyes of Empress and courtiers should symbolize the Shakyamuni Buddha's emergence in Japan (IBID, p. 145).

In the same year, the Empress openly expressed her intention to build the Buddhist temples and encourage the dissemination of "internal books" (naiden 内典), i.e. Buddhist literature in a special decree. So, after two months, she ordered to Crown Prince Shōtoku to make the public lectures (kōjite 講じて) on the Buddhist sutras “The Lion Roar of Queen Shrimala" (Sc. "Shrimaladevisimhanadasutra, Jp. "Shōmangyō” 勝鬟經) and "Lotus Sutra" (Sk. "Sudharmapundarica sutra", Jp. "Hokkekyō" 法華經). When the Prince made it successfully in the Palace of Okamoto, then, according to the "Nihon Shōki", the Empress was very happy about that event and granted to Prince lands in the province of Harima (IBID).

The main content of the "Shrimaladevisimhanadasutra" are the Buddhist sermons on behalf of Shrimala, the daughter of the King Prasenadjit of ancient Indian State of Kosala, who became the wife of the King of Ajodhya. She tells about the One Vehicle of Buddha and explains to her audience that they originally have a Buddha-nature ("Lion's Roar of Queen Shrimala: A Buddhist Scripture on the Tathagatagabha theory", 2007, p. 53). Most likely, Suiko chooses this Sutra for public reading, not only for its relative accessibility to the court audiences, but to draw a parallel between herself and Queen Shrimala. Probably, thus the Empress would like to strengthen her credibility. 
It should be noted that Suiko came to power, when Minister Soga-no Umako, killed the former Emperor Sushun and, obviously, she wanted to underline the legitimacy of her authority with the help of Buddhism. Thus could explain, why the "Lotus Sutra" was also selected for public reading. As for the "Lotus Sutra", it contains the argument, attributed to the Buddha, that a woman could become a Buddha and preach Dharma. It is possible that by that way, Suiko would like to justify their status as Empress, extending and preserving the teachings of the Buddha in the country. In this regard, it could be mentioned that in the temple chronicle "Gangōji Garan Engi", is contained a text, where Prince Toyōtomimi (Shōtoku-Taishi) calls Suiko the "Empress of Dharma" and quote from chapter XXIV of the "Lotus Sutra"-_Bodhisattva Wonderful Sound": "In the Palace of the Emperor a woman will settle down and preach Dharma" (Gangoji garan engi, 1975, p. 97).

In 624, the Empress decided to establish the state control over the Buddhist Sangha (the reason was a crime committed by one of the monks). During this time were established the posts of sojō 僧正 and sozu 僧 都 to control the monks and nuns (kengyō sōni 検校僧尼). This was a foundation of the future religious Office of Priestly Affairs "Sōgō" (僧綱). A Buddhist monk from Baekje Kwal'yok 觀勒 was appointed as sojo, and a government official Tokushaku 徳積 as sozu. By the official order, was conducted a census of Buddhist temples, monks and nuns. According to it, during the reign of Suiko there were 46 Buddhist temples, 816 monks and 569 nuns, in total, 1,385 Buddhist clergymen in the country ("Nihon Shōki”, V. II, 1973, pp. 140-141). This number looks quite realistic, since the archaeological excavations confirm the existence at this time about 50 Buddhist temples.

However, the modern researcher of the ancient Japanese Buddhist archaeology Donald F. McCallum considered that these estimates did not reflect the reality of this period. According to him, 46 of 50 Buddhist temples were concentrated in the district capital of Asuka and its surroundings. As for the number of monks - 1,385, as suggested by McCallum, it looks too high, even considering that in the large Buddhist temples, such as Asuka dera, there were more monks than in others (McCallum, 2009, pp. 28-29).

In this regard, McCallum advances the theory that in the number of monks and nuns could also be included the other people, associated with the Buddhist temples: temple servants, guards, managers, etc. McCallum also considers that the true initiator of the temple census could be a Minister Soga-no Umako, because, in his point of view, it was the Soga clan, who support the spread of Buddhism in Japan during Asuka period (IBID). Yet, as I consider, "Nihon Shōki" is quite explicit about the fact that the initiative of the census of Buddhist temples came from the Empress Suiko, though, it is not excluded that Soga-no Umako could control this process.

Simultaneously with the introduction of Buddhism in the system of government, in the reign of Suiko, in 603 also was introduced the 12 state rank system (kan'i junikai), borrowed from China. In the same year was erected the palace Owarida-no miya, which structure, as considered Osumi Kiyoharu, descended to the Chinese imperial palaces of the Sui dynasty. According to its creators thought, it should be the first Imperial Palace for managing the state affairs and court ceremonies (Osumi, Tokyo, 2010, p. 68). In the following year was introduced a system of court etiquette, directing the officials to enter and leave the Imperial Palace in accordance with the rules based on Confucian etiquette.

It should be noted, that at the beginning of the VII century in Japan, Confucian culture and Buddhism was disseminated mainly by the Buddhist monks from Korea, arrived in Yamato at the invitation of Empress Suiko. They had to train young aristocrats not only in Buddhist philosophy, but also in other sciences: astronomy, geography, the arts of the calendar, as well as Taoist magic. The mentor of these sciences for courtiers became 
a monk Kvankyn, come from Baekje, and another monk Hyoja became a teacher of Prince Shōtoku and was closely related with him until his death ("Nihon Shōki", V. II, 1973, p. 133).

Upon the further study of historical sources, it becomes clear that the successors of Suiko also actively contributed to the prosperity of Buddhism in the country. From the latter half of the seventh century, the state adopted policies to actively promote Buddhism, such as the construction of temples and statues, the sponsorship of rituals (hoe) and the copying of sutras, and the promotion of monks and nuns. The era of Empress Jitō 持統 (686-697) was a turning point.

\section{Empress Jitō Religious Policy}

Being a remarkable politician, Empress Jitō decided to use the Buddha's Dharma in order to assimilate emishi 蝦夷— the northern tribes of the Japanese archipelago, standing at a lower level of social development. As informs "Nihon Shōki", these tribes were conquered during the reign of the legendary Emperor Jimmu. In fact, the Japanese emperors had to carry out a series of military campaigns during the several centuries before emishi became their subjects. Empress Jitō, unlike her predecessors, who considered emishi as barbarians, allowed them to practice Buddhism and taking Buddhist percepts. Because the Buddhist monks were exempted from the taxes and labor obligations, this fact equated emishi with the rights of the other Japanese people (“Nihon Shōki", V. II, 1973, pp. 214-215).

In 689, the two representatives of the emishi-brothers Maro 麻呂 and Kanaori 鐵折 asked the official permission to take percepts and became the Buddhist monks (lit. "asked to shave their hair and become shramana"-koiteki binpatsu nashite shamon 請剔䰎髪爲沙門). The Empress allowed them to take tonsure, because, as she declared: "While Maro and [his brother] are still young, they have gentle [heart] and no [worldly] desires (kanga kayoku 閑雅寡欲). They desire to eat vegetables and hold [Buddhist] percepts (kusabira tabete, jigai 蔬食持戒). So, let them, according to their desire, become monks and training in [Dharma] (shukke shūdō 出家修道)”(IBID).

The Buddha image and ritual items for Buddhist ceremonies granted another monk-Dōshin, who also belonged to the emishi tribe. (IBID) Jito also has encouraged the spread of Buddhism among the emishi, presenting to those, who took Buddhist monastic vows, monastic garments and ritual objects. By her edict, in 692, in the province of Oposumi and Ato (modern prefecture Kagoshima on Kyushu Island), the lands inhabited by the tribes of hayato, were sent the Buddhist missionaries (IBID, p. 225). These records from "Nihon Shōki" could be the evidence, that from the reign of Jitō, the authorities began to use Buddhism for the integration of local tribes into the state ideological system.

In the annals are frequently mentioned the generous donations in the form of land, given by the Empress to Buddhist temples. For example, in 686, the Daiganji temple 大巌寺 was promoted by 700 yards, the temples of Hinokuma-dera 桧隈寺, Karu-dera 輕寺, Okubo-dera 大窪寺 were promoted by 100 yards, and a temple Kose-dera 巨勢寺 had received 200 yards (IBID, pp. 215-216).

It is noteworthy that at the end of her life Jitō took tonsure and became a Buddhist nun. As Yoshida Kazuhiko points out, Jitō sought to establish a state based on Chinese models of legal codes, the construction of a capital, and the compilation of a national history. Religious policy called for a dual religious foundation for a newly reborn Japanese state based on both jingi/kami rituals and Buddhism. Japanese myths were created, providing a literary expression for the imperial transmission through a single family lineage. Elements of Buddhism based on the Suvarnaprabsa Sutra were appropriated for state rituals that were to be performed 
across the country. The state also provided regulations for the ordination of monks and nuns, borrowing the Chinese system for state recognition of ordinands. The number of annual official ordinations (nenbundosha) was set at ten. The capital (Fujiwara-kyõ) established by the empress was lined with splendid state supported temples such as Yakushi-ji, and she was cremated after her death (Yoshida, 2003, p. 7).

\section{Empress Kōken (Shōtoku) and the Chinese Empress Wu Hou}

Jitō was the first Japanese empress, openly taking the tonsure, and this could serve as an example for the other Japanese Empress Kōken 孝謙 (Shōtoku 稱德) (756-783), who, becoming a Buddhist nun, continued to rule the state. In the decree of Empress Kōken from 757 is told about the disclosure of the conspiracy by the Minister of the Court Tachibana-noNaramaro to overthrow the Empress. The assistance in the disclosure of the conspiracy is attributed to the gods-kami and the Buddhist deities: Vairochana Buddha (Jp. Birushana Butsu 毘 盧遮那仏), Bodhisattva Avalokitesvara (Jp.Cannon Bosatsu 観音菩薩), Brahma (Jp. Bon’o 梵王), Indra (Jp. Taishakuten 帝釈天) and the Four Heavenly Kings (Jp. Shiteno 四天王) (“Shōku Nihongi”, V. II, 1973, p. 235). In the decree of 764 on exposing the other conspiracy of Minister Fujiwara Nakamaro 藤原仲麻呂 (706-764), the Empress Kōken, (also becoming a Buddhist nun and taken another name-Shōtoku), quotes from the Buddhist sutras apparently, from the "Sutra of golden light" (Sk. "Suwarnaprabhasa sutra", Jp. “Konkomyōkyō" 金光明經) as an evidence of her rights to the throne:

And so We took vows and wore the sacred Buddhist robe, but it is impossible for Us not to rule the state affairs of [our] celestial country. And the Buddha in the Sutra thus have told: "The Lord of the Kingdom during his reign must take the Bodhisattva precepts (kokuō kokui nizaji wo bosatsu sunawachi jōkai ukete 國王王位坐時菩薩淨戒受).” And, at least, We left the house (became a nun), but now [there] is no obstacles for Us to make the state affairs (seigyo ni ani sawari mono fuzai 政行豈障物不在). (“Shōku Nihongi”, V. II, 1973, pp. 288-289)

This decree of Kōken could serve as an example of the origins of insei system of government of the later X-XII, when the retired emperors had more freedom of action, than their successors, whose power was limited by the activity of the regents from Fujiwara clan.

It should be noted, that in the decree from 765 on the celebration of the Shinto ceremony of the first harvest Oonie-no matsuri 大䞇の祭り, Kōken openly proclaims her Buddhist policy:

“Therefore, first of all, We want to serve the Three Treasures (sanbō 三宝), then to honor the gods of Heaven and Earth ( $k a m i$ 神), then to take care about our officials princes, nobles, the officials of one hundred departments and all the people of the Celestial Empire. So We suppose to rule our Celestial Empire" (IBID, p. 295). In her other decrees in future, the words "The Law of the Buddha" (buppo 仏法) and "The Three Treasures" (Buddha, Dharma and Sangha) (sanbō 三宝) would always come first.

In second, the empress asserts about the unity of Buddhism and traditional Japanese religion Shinto, allowing both laity and Buddhist monks to take part in Shinto religious ceremonies without passing the Shinto rite of purification. As it is stated in the decree: "And yet I proclaim: people thought that they could be in contact with the gods-kami 神 only by avoiding the Three Treasures. However, if to look in the Sutra, there [is written] that all the deities protected and honored Buddha's sacred Dharma" (IBID, pp. 295-296).

Allowing the descendants of Buddhism-monks and laity to participate in Shinto rituals without undergoing the rite of purification harae 袯元, Kōken thus stressed that Buddhists were not the beings, carrying the threat of desecration to Shinto rituals. On the contrary, they could be full participants in Shinto 
ceremonies, because by means of this decree, both Buddhism and Shinto are the sacred religions of the Japanese people.

This fact shows that Kōken continued the religious policy of her father-Emperor Shōmu 聖武 (701-756), encouraging a Shinto-Buddhist syncretism. The Buddhist policy of Empress Kōken largely was determined by the difficulties of her reign. Just two years after ascending the throne, she was removed from power by the coalition that united retired Empress Kōmyō and Great Minister Fujiwara Nakamaro. Kōken was forced to abdicate in favor of the Crown Prince Ooi (733-765) (future Emperor Jūnin 淳仁), but due to the support of the monk Dōkyō 道鏡, she was able to regain power. During the joint reign of Dōkyō and Kōken, several measures were taken to strengthen and control the Buddhist Church. The Buddhist hermits were prohibited to build Buddhist temples in the mountains and forests without official permission. During this time was strengthened the state control over the expenditure of funds, allocated for the provincial Buddhist monasteries. At the same time, the government allocated significant sums and land donations to the Buddhist temples (Abe, 1999, pp. 21-22).

It is noteworthy that many researchers (Paul Williams) have compared Kōken with the Chinese Empress Wu Hou 武后 (625-705), who also relied on the Buddhist clergy and sought to justify her actions, based on the Buddhist concept of chakravartin - the ideal Buddhist king. The empress $\mathrm{Wu}$ used a variation of this concept outlined in post-canonical "The Great Cloud Sutra" (Sk. "Mahamegha-sutra", Ch. "Da Yun Ch'ing" 大雲經), which tells about a naga (dragon) girl, who after the death of her father-dragon King was destined to become ruler of the world. From the official biography of Wu Hou is known that she publicly adopted the title of "The great Sage-King of the Golden Chakra" (Jin lun da sheng) and placed in their apartment the so-called treasure-gem — one of the seven standard treasures attributed of the universal ruler—chakravartin (Buddhism: Critical concepts on religious studies, 2005, V. VIII, pp. 26-28).

It can be assumed that such coincidence was a tendency among the female monarchs in the Far East. In a Confucian society, restricting the social activity of women only by family life, women have tried to assert their social position through the participation in the life of Buddhist Sangha.

Later, with the spread of Buddhism in the Far East and South-East Asia, mainly due to the patronage of wealthy laywomen, Buddha's teachings became a part of the State ideology. In China, during the period of Six Dynasties, according to Valentina Georgieva, the women who belonged to the elite of Chinese society founded the first female Sangha in China. In this period, many of the Chinese Empress and noble ladies, fleeing from distemper and palace intrigues, sought refuge in Buddhist monasteries (Georgieva, 2000, p. 198). For example, the mother of Yang Guang (楊廣), 一 the founder of Sui dynasty (581-618), was hiding in a convent, where she bore and raised her son (IBID, p. 188).

During the Tang period, many laywomen donated land and the gifts to the Buddhist monasteries in such amounts, that the emperor Huantzun (712-756) had issued a special decree in 709 , trying to stop the uncontrolled transfer of the land ownership.

\section{Conclusion}

If the contribution of Chinese empresses in the spread of Buddhism in China was mostly confined by the donations to Buddhist temples and monasteries, the Japanese Empresses of Asuka and Nara periods (VI-VIII centuries) had set up a state program for the transformation of Buddhism in the official ideology. In the world of state Buddhism and the Buddhism of the imperial court, there were many empresses, as well as other women 
at the court, who pursued policies that strongly supported Buddhism. Many women in aristocratic circles also supported Buddhism, and the historical records reveal that they were active in the production of Buddhist images and paintings, and in sutra copying. Due to the activity of the empresses Suiko, Jitō and Kōken, the integration of Buddhism into the system of traditional beliefs led to the bases of "ryobu-sinto" Shinto-Buddhist syncretism. Through all the country, hundreds of the Buddhist temples had been constructed. Its inhabitants Buddhist monks spread also the continental, Chinese-Korean high culture on which the basis of unique Japanese culture further has grown. With the help of Buddhism, were made attempts to unite the Japanese people and the barbarian tribes hayato and emishi. What is the most important, in this period were created the favorable conditions for the development of the Buddhist philosophical schools that later led to the appearance of a traditional Japanese Buddhism.

\section{References}

Alex, \& Wayman, H. (Ed.). (2007). Lion's roar of Queen Srimala: A Buddhist scripture on the Tathagatagabha theory. Delhi: Motilal Banarsidass.

Georgieva, V. (2000). Buddhist nuns in China: From the Six Dynasties to Tang. Leiden: University of Leiden.

Katsumi, K. (Ed.). (1973). Nihon shōki (“Annals of Japan”) // Kokushi taikei (Studies on national history). Tokyo: Yoshikawa Kobunkan.

Katsumi, K. (Ed.). (1973). Shōku Nihongi ("Continuation of the "Nihon Shōki”) // Kokushi taikei (Studies in national history). Tokyo: Yoshikawa Kobunkan.

Kazuhiko, Y. (2003). Previsioning religion in ancient Japan. Japanese Journal of Religious Studies, 30, 1-26.

Osumi, K. (2010). The acceptance of the Ritsiryo codes and the Chinese system of rites in Japan. Studies on the Ritsuryo system of ancient Japan. In comparison with Tang. Acta Asiatica, 99, 59-79.

McCallum, D. (2009). The four Great Temples: Buddhist archeology, architecture, and icons of seventh-century Japan. Honolulu: University of Havai'i Press.

Ryuichi, A. (1999). The weaving of mantra. Kukai and the construction of esoteric Buddhist discourse. New York: Columbia University Press.

Tokutaro, S. (1975). Gangoji garan engi. Jisha engi (The records about the foundation of Gangoji temple and its treasures) // Nihon shiso taikei (Studies on Japanese Philosophical Thought), V. XX, Tokyo: Iwanami Shōten.

Williams, P. (Ed.). (2005). Buddhism: Critical concepts on religious studies. New York: Routledge. 